Vojkan B. Stojičić

University of Belgrade

Faculty of Philology, Department of Modern

Greek Studies

vojkans@ hotmail.com

\section{Martha P. Lampropoulou}

University of Belgrade

Faculty of Philology, Department of Modern

Greek Studies

marthalamp@gmail.com
Original research paper

UDC: 811.14'06-057.875(=163.42)

DOI: 10.19090/MV.2021.12.319-337

\title{
PERFECTIVE AND IMPERFECTIVE ASPECT: A CASE STYDY OF L2 SERBIAN STUDENTS OF MODERN GREEK ${ }^{1}$
}

ABSTRACT: This paper attempts to highlight common errors made by Serbian learners of L2 Modern Greek in relation to verbal aspect. It begins by exploring terms such as aspect and perfectivity in the Modern Greek language and then presents an analysis based on the written performance of our sample group. This analysis is crucial since it examines the way in which the written production of the participants evolved over the four years of their academic studies, something that deepens our understanding of the way this grammatical area is acquired by Serbian learners.

Key words: perfective aspect, imperfective aspect, Modern Greek as a foreign language, Serbian students.

\section{ПЕРФЕКТИВНИ И ИМПЕРФЕКТИВНИ АСПЕКТ: СТУДИЈА СЛУЧАЈА СТУДЕНАТА НЕОХЕЛЕНИСТИКЕ}

АПСТРАКТ: Рад покушава да укаже на уобичајене грешке у вези са глаголским аспектом код српских студената који уче модерни грчки језик као страни. На почетку рада указано је на појмове аспекта и перфективности у модерном грчком језику, те је потом представљена анализа резултата заснована на писменим радовима наше групе испитаника. Ова анализа од изузетног је значаја, будући да испитује начин на који се писмена продукција испитаника развијала током четири године основних академских студија, што нам помаже да боље разумемо начин на који српски студенти усвајају ову граматичку категорију.

Кључне речи: перфективни аспект, имперфективни аспект, модерни грчки као страни, србофони студенти.

\footnotetext{
${ }^{1}$ The paper is the result of research conducted within project no. 178002 funded by the Ministry of Education, Science and Technological Development of the Republic of Serbia.
} 


\section{INTRODUCTION}

This longitudinal study investigates the way in which 15 Serbian learners interpret and express the notion of aspect in Modern Greek in terms of the subjunctive and future tense constructions. It is one of the most challenging grammatical areas for foreign learners of Modern Greek with a considerable number of errors observed. This is also the case with Serbian-speaking students who study at the Department of Modern Greek Studies at the University of Belgrade. The study has two parts. In the first part, the expression of verbal aspect and subjectivity in Modern Greek is explored and specific examples are juxtaposed with their equivalents in Serbian. As Veloudis (1989) and Moser (1994, 2005) note, all languages have the means to express time, perfectivity or aspect; therefore, a semantic and morphological comparison is made between the two languages.

The second part of the paper investigates the understanding of aspect by a group of 15 Serbian students from the Department of Modern Greek Studies at the University of Belgrade, based on their written performance. We collected essays from the same 15 students from their first year of studies until their fourth year. More specifically, the data were collected from a body of 60 short essays over an extended period of time: from the 2014-2015 academic year to the 2017-2018 academic year. The essays were part of their spring semester exams. The participants were asked to write a short essay on a given topic. The type of essay was an important factor in our study as it involved directional discourse (topics which required giving instructions or advice), which favors the use of both the perfective and the imperfective. The results showed that verbal aspect is a "vulnerable area of the grammatical domain" (Mattheoudaki, Kitsou and Tzimokas 2011; Papadopoulou 2005; Drettas 1987), but also that our students acquire aspect to a satisfactory level by the end of their studies. Their erroneous choices when it comes to the perfect or the imperfect subjunctive mainly depend on the context and less on syntax or grammatical rules. Moreover, there is a tendency to use the imperfective instead of the perfective, something that reveals negative transfer from their mother tongue. Based on our findings and the relevant literature, this study suggests ways to address these errors which stem from mother tongue influence in order to improve the teaching of Modern Greek as a second/ foreign language. 


\section{VERBAL ASPECT IN MODERN GREEK}

Verbs describe motion or denote an action and they can be put into three categories of mood in Modern Greek (Joseph \& Philippaki-Warburton 1987; Tzartzanos 1946; Triantaphyllides 1941): a) the indicative, which states an event or poses a question, $b$ ) the subjunctive mood, which is used to express wishes, to give instructions and to state possibility, and c) the imperative mood, which is used to order and/or to require. Beside the volition of the speaker, the verbs are also characterized by aspect, which shows the attitude of the speaker. There are two types of aspect: perfective and imperfective. As Holton et al. explain, the imperfective indicates that the action is "in progress, habitual or repeated" (1999: 110), while the perfective shows that the action is seen as "completed" (ibid.).

As the following figure shows, a change of aspect means a difference in the stem, although the inflections remain the same. The perfective-imperfective distinction is present in the present and the past tenses, as well as in the subjunctive and the imperative mood.

\begin{tabular}{|c|c|c|}
\hline & Imperfective & Perfective \\
\hline \multirow{4}{*}{$\begin{array}{l}\text { Present } \\
\text { (non-past) }\end{array}$} & $\gamma \rho \alpha \dot{\alpha}-\omega$ & $\gamma \rho \alpha ́ \psi \psi \omega$ \\
\hline & ghraf-o & ghraps-o \\
\hline & (write-Imp)-1s & (write-Perf)-1s \\
\hline & 'I write, I am writing' & Dependent \\
\hline \multirow[t]{4}{*}{ Past } & $\dot{\varepsilon}-\gamma \rho \alpha \varphi-\alpha$ & $\dot{\varepsilon}-\gamma \rho \alpha \psi-\alpha$ \\
\hline & e-ghraf-a & e-ghraps-a \\
\hline & (write-Imp)-1s & (write-Perf)-1s \\
\hline & 'I was writing, I used to write' & 'I wrote' \\
\hline \multirow[t]{4}{*}{ Future } & $\theta \alpha \gamma \rho \alpha \dot{\varphi} \varphi-\omega$ & $\theta \alpha \gamma \rho \alpha \dot{\psi} \psi-\omega$ \\
\hline & tha ghraf-o & tha ghraps-o \\
\hline & (write-Imp)-1s & (write-Perf)-1s \\
\hline & 'I will write (e.g. often)' & 'I will write' \\
\hline \multirow[t]{5}{*}{ Imperative } & $\gamma \rho \alpha \dot{\varphi}-\varepsilon$ & $\gamma \rho \dot{\alpha} \psi-\varepsilon$ \\
\hline & ghraf-e & ghraps-e \\
\hline & (write-Imp)-1s & (write-Perf)-1s \\
\hline & 'Write (e.g. often)' & 'Write (e.g. now)' \\
\hline & seph 1983, Tsanga & ton et al. 1997: 111 \\
\hline
\end{tabular}

Figure 1. Perfective and imperfective aspects in Modern Greek (from Tsangalidis 1998: 310). 
Apart from the attitude of the speaker, perfectivity is connected to evidentiality and telicity, i.e. the speaker presents the action as feasible or not, based on evidence, especially in cases where the speaker proposes or makes suggestions/recommendations. Yet, in all cases, morphology and syntax set constraints on the semantics of the verb forms (Koutoupi-Kiti \& Tsangalidis 2002; Psaltou- Joycey 2003: 2; Roussou 2015: 170-180).

At a more theoretical level, there is a lot of debate about the way mood and modality are defined diachronically (Charleston 1941, in Van Der Auwera \& Zamorano 2016). Moods are treated with caution and doubt by contemporary linguists and grammarians alike (Lakoff 1968; Lightfoot 1979). The main area of debate in Modern Greek concerns the formation of subjunctive types in a periphrastic manner and/or the marking of certain particles as components of moods, i.e. the negation « $\mu \eta v »$. For instance, the subjunctive mood is identified primarily by means of preverbal particles, mainly the particles $n a$ ('to') and as ('let's', 'let him/her', etc.), particles which according to Lakoff (1968: 161) are devoid of meaning. Similarly, Lightfoot (1979: 48) supports the idea that the particles of the subjunctive in Modern Greek do not carry "any distinctive meaning of their own". In addition, the subjunctive is diachronically questioned in terms of semantics $^{2}$. As Goodwin claims (2011: 374-375), the subjunctive originally expressed future time and this simple future meaning is found "in general suppositions". All this has given rise to differing presentations of its functions in the various grammars of Modern Greek.

\section{ASPECT IN SERBIAN}

Differing views on modality have been expressed for Serbian grammar, too. According to Piper and Klajn (2013: 183), there are three moods: the indicative, the imperative, and the optative. However, Stanojčić (2010: 164) defines moods as: the imperative, the optative and the future. On the other hand, Piper et al. (2005: 453) claim that there are only two moods in the Serbian verb system: the imperative and the optative, through which modality is expressed. The latter also consider the primary role of mood to identify the action denoted by the verb as real (related to appearance and time) or unreal (Piper et al. 2005: 1003).

\footnotetext{
${ }^{2}$ In general, the issue of whether mood should be specified formally only by means of verbal morphology is still being debated (Van Der Auwera \& Zamorano 2016).
} 
Despite the confusion or the disagreement in typology encountered in Serbian, Serbian grammar makes the following distinction:

Verbs:

a) Verbs with perfective aspect

1) Čim pojedem tortu na terasi, ići ću na utakmicu.

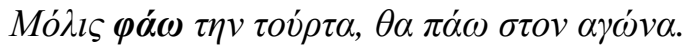

When I have eaten the cake, I will go to the game.

b) Verbs with imperfective aspect

2) Sedim i jedem tortu na terasi.

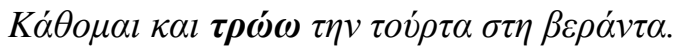
I am sitting on the porch and eating cake.

c) Verbs with two aspects. The aspect depends on the semantics.

3a) Sedim na terasi i telefoniram Janisu.

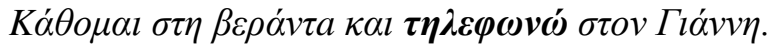

I am sitting on the porch and I am calling John.

3b) Čim telefoniram Janisu, poslaću ti poruku.

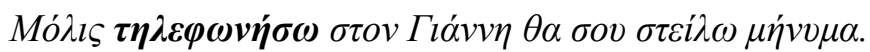

When I have called John, I will send you a message.

In the following example, we can see an aspectual difference between Modern Greek and Serbian.

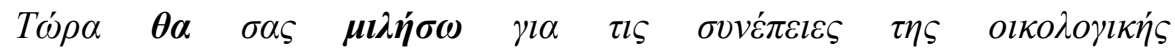
$\kappa \alpha \tau \alpha \sigma \tau \rho o \varphi \eta \dot{s}$.(perfective)

Sada ću vam govoriti o posledicama ekološke katastrofe. (imperfective)

Now I am going to talk to you about the consequences of ecological destruction.

\section{TEACHING THE PERFECTIVE AND THE IMPERFECTIVE ASPECT IN MODERN GREEK}

Serbian learners of Modern Greek are taught the tense system and the moods in the first year of their studies, by the end of which they are expected to have reached the A2 level. They become familiar with semantically ambiguous 
types of aspect during the third and fourth years, when they get a grasp of the subtle nuances.

However, at an early stage, teaching involves examples in Modern Greek accompanied by their equivalent in Serbian. Students receive feedback from both the Serbian members of staff and native speakers of Modern Greek working at the Department, who teach grammar jointly. In the current study, aspect will be investigated in the subjunctive and in the future tenses in Modern Greek. Both areas provide appropriate ground for us to explore the notion of perfectivity.

The subjunctive is formed by particles and conjunctions preceding the main verb (i.e. $v \alpha, n a$ ). The same applies to the future in Modern Greek (i.e. $\theta \alpha$, tha).

The various forms of write in Modern Greek ${ }^{3}$ :

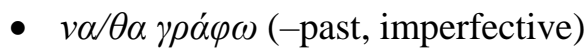

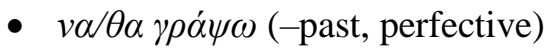

- $v \alpha / \theta \alpha \dot{\varepsilon} \gamma \rho \alpha \varphi \alpha$ (+past, imperfective)

- $v \alpha / \theta \alpha \dot{\varepsilon} \gamma \rho \alpha \psi \alpha$ (+past, perfective)

and in Serbian:

- Да пишем/nuсаћy (-past, imperfective)

- Da napišem/napisaću (-past, perfective)

- Da sam pisao/pisao bih (+past, imperfective)

- Da sam napisao/napisao bih (+past, perfective)

Modality in sentences with $n a$ or tha is defined by means of the morphological characteristics of $+/-$ past, +/- telic (Roussou 2015: 186) ${ }^{4}$. However, the particle an is syntactically and semantically 'fuzzy'. According to Triantaphyllides (1941: §1061), an can be characterized as a particle, but also as a conjunction. This dual nature of its syntactic identity has been the subject of different approaches and differing analysis ${ }^{5}$.

\footnotetext{
${ }^{3}$ Indicative examples translated into English will be provided below.

${ }^{4}$ Modality in Modern Greek, apart from moods, is also denoted by means of adverbs such as í $\sigma \omega \varsigma$ (perhaps) and $\pi \imath$ avóv (possibly), and other constructions (Holton, Mackridge \& Filippaki-Warburton 1999: 204-212).

${ }^{5}$ It should be noted that the dependent clause that is introduced with $n a$ can occasionally allow switch reference, either implying a single subject or a different one. For example, in the following sentence:
} 
The verbs which precede subjunctive forms usually express volition (want, wish, etc.), modality (can, must, might, etc.), perception (remember, forget, consider etc.), feelings (I am happy, I am sorry, etc.) and cognition (know, learn, etc.) (Roussou 2015: 188).

In order to exemplify verbal aspect for students and to cover any subtle nuances, teaching involves the juxtaposition of equivalent sentences.

Examples in the target language and in the mother tongue respectively ${ }^{6}$ :

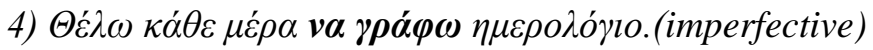

Hoću svakog dana da pišem dnevnik. (imperfective)

'I want to write a journal every day.'

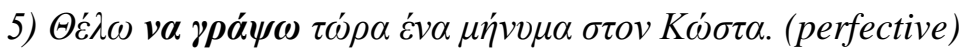

Hoću da napišem sada poruku Kostasu. (perfective)

'I want to write a note to Kostas.'

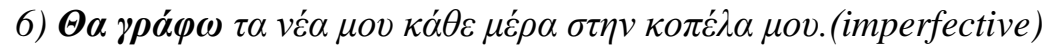

Pisaću svakog dana svojoj devojci novosti.(imperfective)

'I will be writing my news to my girlfriend every day.'

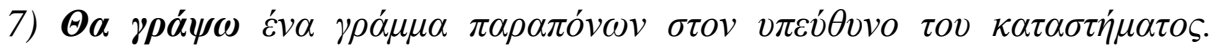
(perfective)

Napisaću pismo žalbe menadžeru prodavnice.(perfective)

I will write a complaint letter to the store manager.'

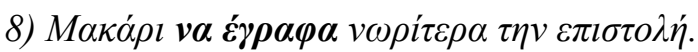

Eh da sam pisao ranije dopis.

I wish I had written this lettere arlier.'

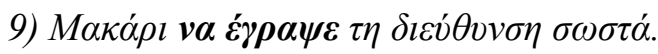

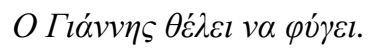

John wants to leave.

Or John wants him to leave.

The subject of the sentence might be John himself, meaning that John is planning to leave, or it could be that John wants (demands) someone else to leave.

${ }^{6}$ The grammatical features in bold cannot be attributed in the English language due to the different type of grammatical realization. 
Eh da je napisao tačno adresu.

'If only he had written the address correctly.'

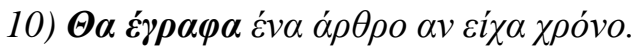

Pisao bih članak kad bih imao vremena.

'I would write an article if I had time.'

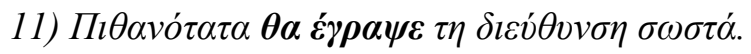

Najverovatnije da je napisao adresu tačno.

'He is likely to have written down the address correctly.'

We see that in Serbian, in addition to the use of da and the conjugation of the verbs, aspect can be marked through adding perfective prefixes to the verbal $\operatorname{root}^{7}$.

Taking into consideration the fact that there are significant differences in the typology of aspect in both languages, it is not surprising that errors may occur on the part of the students, especially during the initial stages of language learning. As Mitsis stresses (1998: 174-197), the moods and the conjugation of verbs are two grammar areas which require special attention. Errors in the verbal aspect made by Serbian students have been recorded and discussed in previous studies (Stojičić \& Lampropoulou 2020; Stojičić, Lampropoulou \& Janković 2019; Rađenović 2017; Vervitis, Kapourkatsidou \& Stojičić 2012). Katsimali (2005: 65-86) and Galanopoulos (2019) also confirm the difficulty which foreign students of Modern Greek have when it comes to distinguishing aspect (perfective or imperfective). More specifically, Galanopoulos (2019) detects such errors in both oral and written production and believes that the teacher should dedicate a lot of time to this area and provide adequate examples. Koutoupi-Kiti \& Tsangalidis (2002) and Psaltou-Joycey (2003: 2) argue that in order to successfully distinguish the morphological forms of perfective and imperfective aspect, the viewpoint of the speaker is of primary importance. Therefore, semantics should be prioritized and exemplified sufficiently during grammatical analysis.

\footnotetext{
7 'In article-less Slavic languages (e.g. Russian, Polish, Czech), the object's quantization does not play a large role in compositional telicity. These languages utilize the verbmarking mechanism of signaling (a)telicity, at least for activities and accomplishments with Incremental Theme objects" (Slabakova 2005: 65).
} 


\section{EMPIRICAL PART}

As mentioned earlier, this study is a longitudinal one: we monitored the progress of students over a period of four consecutive academic years by examining their written production at each level: A1, A2, B1, B2-C1. A total of 60 essays were collected. The topics revolved around everyday life and the degree of difficulty varied depending on the level, e.g. advertisements or a letter to a friend (A1, A2), a letter or an article (B1, C1).

\subsection{Material}

More specifically, the material was collected from a number of essays, which were part of a spring semester mid-term evaluation. Overall, a total of 60 essays were collected from 15 students with four sample essays from each participant (one from each academic year). The form of these essays ranged from personal letters to friends or relatives (narration of personal plans and special occasions) and advertisements (e.g. renting a house) to formal emails or newspaper articles on everyday issues (e.g. recycling, health and nutrition, etc.). The topics of these essays were as follows:

Written task 1 (A1) - 2014-2015 academic year: "Write three different newspaper advertisements: a) a marriage announcement, b) a property advertisement - a house to rent, and c) a job advertisement - asking for a private Math tutor."

Written task 2 (A2) - 2015-2016 academic year: "You have graduated from high school and you are thinking about what the best options for your future studies are. Write a letter to a friend asking for advice."

Written task 3 (B1/B2) - 2016-2017 academic year: students had to elaborate on one of five topics: "Discuss the advantages and disadvantages of cloning", "Discuss whether people use their free time wisely", "Discuss contemporary unhealthy eating habits and propose solutions", "Discuss why it is important to preserve culture and tradition" and "Discuss why travelling is important in life".

Writing task $4(\mathrm{C} 1 / \mathrm{C} 2)$ - 2017-2018 academic year: students had to elaborate on one of five topics: "Write an article for a newspaper on the impact of advertising on the younger generation and propose solutions", "Write an article on the influence of the most widely spoken and dominant languages over other weaker ones", "Write an article on museums and the utilization of cultural resources", 
"Write an article on euthanasia and its implications" and "Write an article on the power of the mass media".

As can be seen, each topic corresponds to a level from A1 to $\mathrm{C} 1 / \mathrm{C} 2$, based on the Common European Framework of Reference (CEFR). In other words, the sample provided us with the possibility to examine the evolution and development of written expression and comprehension of modality and tropicality in Modern Greek of each participant over four consecutive annual midterm exams from A1 to $\mathrm{C} 1 / \mathrm{C} 2$ level. More specifically, aspect was studied with regard to the future tenses and the subjunctive as the theme of the examined material favored the use of such forms, especially when the subjects proposed potential solutions. Therefore, all perfective and imperfective forms of future tenses and of the subjunctive were recorded and will be further analyzed.

\subsection{Participants}

Fifteen students took part in the study: 3 males and 12 females, aged around 21 or 22 years old. The criterion for their selection was their satisfactory performance: a) their average score was 5 points or above (on a scale of 1-10) and b) they were students who did not repeat any semester from the start of their studies until the fourth year (2017-2018 academic year). It is important to stress that students enrolling at the Department of Modern Greek Studies start from a beginners' level according to the Common European Framework of Reference for Languages.

\subsection{Results}

A total of 749 instances of aspectual forms were recorded in the 60 examined essays. These forms were subjunctive and future tense constructions. Subjunctive forms comprised $80 \%$ (599) of this total, with instances of future forms accounting for a mere 20\% (150), as can be seen in Figure 2 below. 


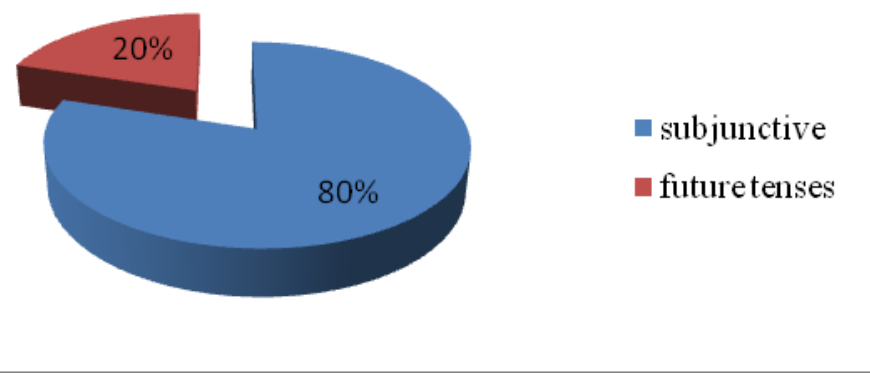

Figure 2. Total of future and subjunctive forms

Moreover, of the 749 instances (of aspectual forms), only 53 (7\%) cases constituted errors in perfectivity (Figures 3 and 4).

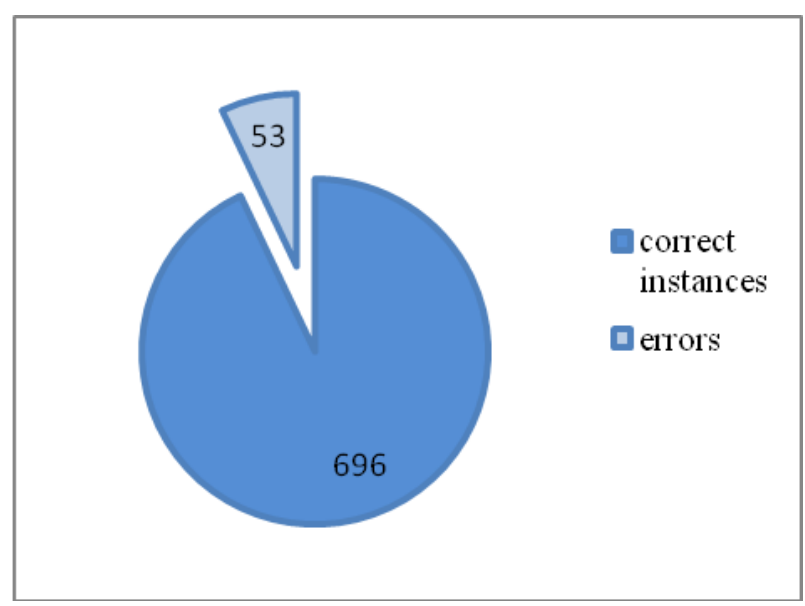

Figure 3. Errors in perfectivity

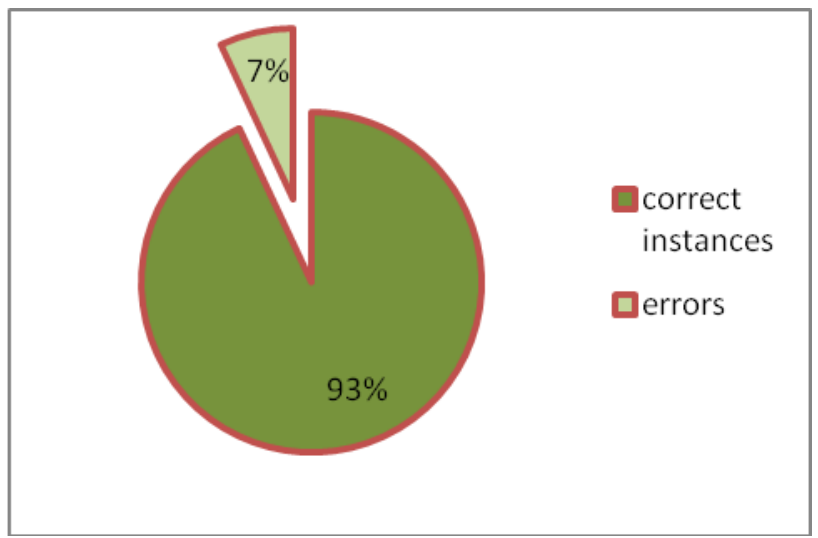

Figure 4. Errors in perfectivity (in percentages) 
The majority of students made very few mistakes in relation to the use of the correct aspectual verbal form (Table 1 and Figure 5).

\begin{tabular}{cccccc}
\hline students & $\begin{array}{c}\text { essay 1 } \\
\text { (errors) }\end{array}$ & $\begin{array}{c}\text { essay 2 } \\
\text { (errors) }\end{array}$ & $\begin{array}{c}\text { essay 3 } \\
\text { (errors) }\end{array}$ & $\begin{array}{c}\text { essay 4 } \\
\text { (errors) }\end{array}$ & $\begin{array}{c}\text { total aspectual } \\
\text { verbal forms } \\
\text { (correct forms } \\
\text { and errors) }\end{array}$ \\
\hline S1 & 1 & 0 & 0 & 0 & 54 \\
\hline S2 & 0 & 0 & 3 & 0 & 48 \\
\hline S3 & 0 & 1 & 0 & 2 & 54 \\
\hline S4 & 0 & 0 & 0 & 0 & 90 \\
\hline S5 & 0 & 1 & 0 & 2 & 44 \\
\hline S6 & $\mathbf{4}$ & $\mathbf{0}$ & $\mathbf{6}$ & $\mathbf{0}$ & $\mathbf{4 8}$ \\
\hline S7 & 0 & 0 & 0 & 0 & 44 \\
\hline S8 & 1 & 2 & 0 & 0 & 47 \\
\hline S9 & 0 & 2 & 1 & 0 & 56 \\
\hline S10 & $\mathbf{0}$ & $\mathbf{0}$ & $\mathbf{5}$ & $\mathbf{9}$ & $\mathbf{4 5}$ \\
\hline S11 & 0 & 0 & 2 & 3 & 53 \\
\hline S12 & 0 & 0 & 0 & 0 & 39 \\
\hline S13 & 0 & 0 & 0 & 1 & 42 \\
\hline S14 & 1 & 0 & 2 & 0 & 42 \\
\hline S15 & 0 & 0 & 3 & 1 & 44 \\
\hline
\end{tabular}

Table 1. Errors per student

\section{erroneous verbal forms (subjunctive and future constructions)}

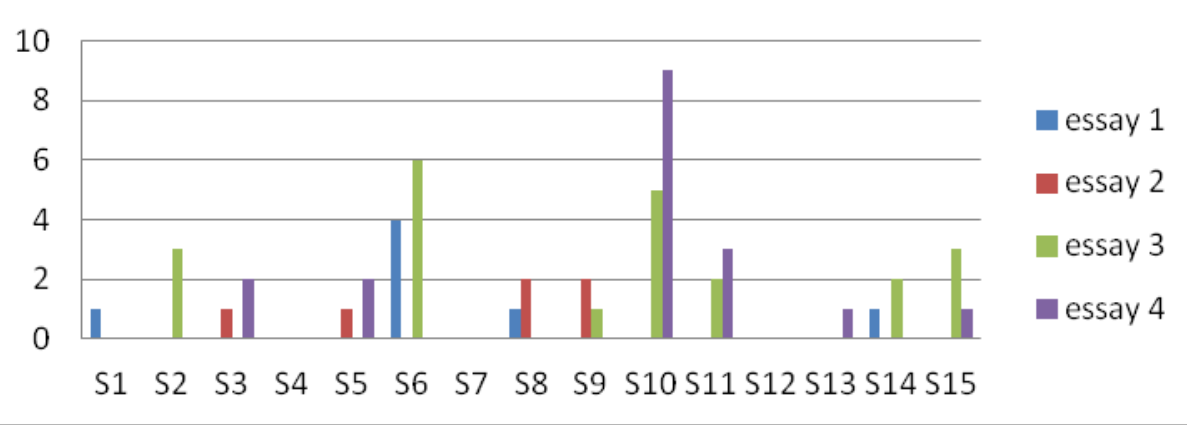

Figure 5. Errors per essay 
Lastly, the findings showed that the use of imperfective forms slightly surpassed perfective ones. However, this depended on the context, which was shaped by the topic itself.

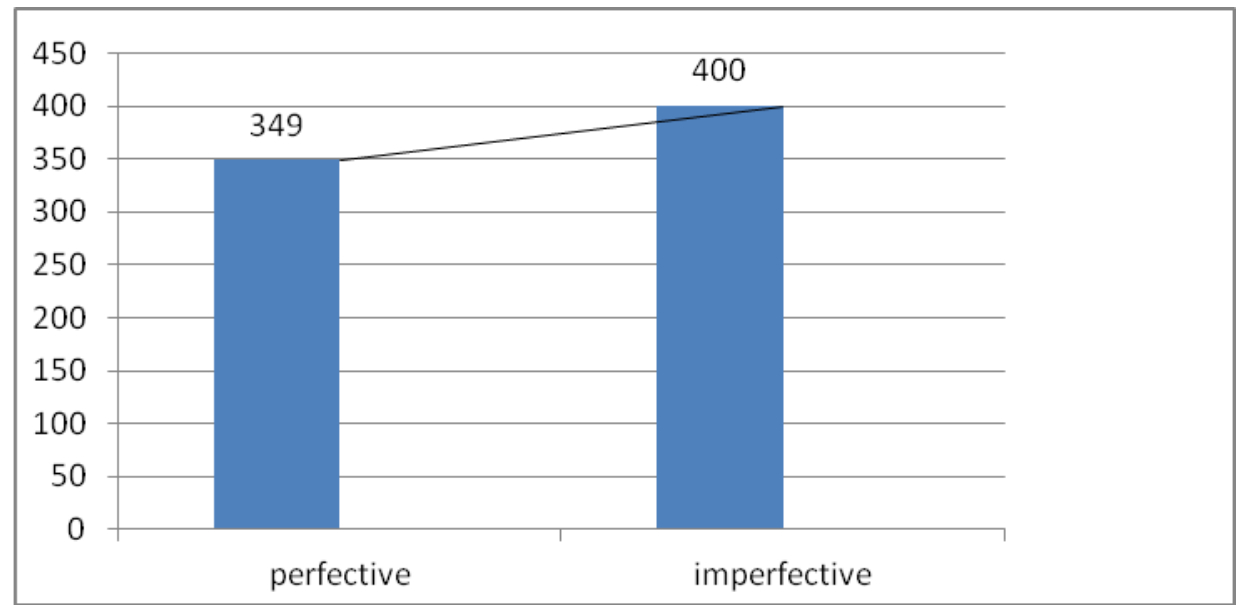

Figure 6. Perfective-imperfective

\section{DISCUSSION}

The findings revealed very few mistakes in the students' overall performance and the errors did not relate to language level. This means that the participants did not exhibit confusion regarding the conceptualization of the perfective forms either at a beginners' level or when at a more advanced level according to the CEFR.

The results can be explained if we take into account the fact that the sample consisted of proficient students and, thus, their progress was remarkable during their four years of studies. Table 4 clearly illustrates that only two students made slightly more mistakes than the rest. Moreover, half of the errors can be put down to negative transfer. In fact, 23 of the 53 mistakes were due to the influence of the Serbian language. For instance, Participant No. 6 was influenced by his mother tongue:

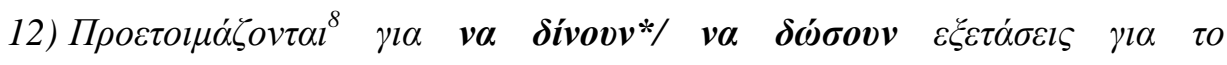

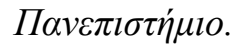

Pripremaju se da polažu prijemni ispit.

\footnotetext{
${ }^{8}$ Talking about final year high-school students who take national exams.
} 
'They are getting ready to take exams for entrance to university.'

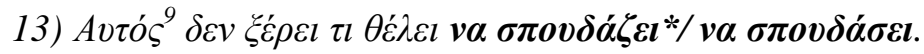

On ne zna šta želi da studira.

'He does not know what he wants to study.'

The student in question used the wrong type of subjunctive. It was apparent that he treated the action as continuous, something that is expected in Serbian (use of the imperfective). However, for a Modern Greek speaker the focus lies in the intention of the action. Both (12) and (13) in Modern Greek highlight the result, that of sitting the exams and starting an academic degree course; therefore, the use of the perfective is imperative.

Last but not least, the frequency of the types of imperfective could be a result of the essay topics. The language of instructions and advice gives precedence

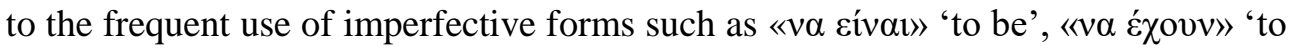
have' - subjunctive forms that denote a state of being, and future forms such as $« \theta \alpha$ $\pi \rho \varepsilon ́ \pi \varepsilon 1 \gg$ 's/he should', which carries a deontic sense. Such cases imply continuity and an atelic sense.

All in all, the context and the intention of the speaker are important factors in the choice of aspect. For this reason, we assume that there is a need for more examples in the classroom in order to ensure a better understanding of the phenomenon.

Adult students can be familiarized with the subjunctive at the beginners' level by means of appropriately tailored activities, such as speaking activities where they would be required to engage in persuasive debates and offer advice. Additionally, it is important to discuss problematic areas in terms of modality, areas where we notice negative transfer from the mother tongue. In turn, it would be helpful to give detailed feedback. These practices could enhance understanding and lead to better grammatical choices of aspect.

\section{CONCLUSION}

This particular study examined the grammatical performance of 15 students in perfective and imperfective aspects during their academic studies at the

\footnotetext{
9 Talking about a student who is about to take national exams in order to continue on to tertiary education.
} 
Department of Modern Greek Studies at the University of Belgrade. Even though the sample size was small, the outcome is useful. Aspect is considered to be a tricky area for foreign learners of Modern Greek. However, the findings show that it is an area that students can successfully master. The few errors were mainly due to negative transfer, something that could be improved with practice. How aspect is taught could be reconsidered and teaching material could be reviewed by going through various linguistic approaches. As our findings show, the role of L1 transfer should be a fundamental factor considered in research, especially when we come across vulnerable interfaces such as "the syntactic to discourse pragmatic one" (Collentine 2010: 43). Consequently, the evaluation of diachronic and contemporary approaches along with the evaluation of feedback may sharpen students' accurate detection of the different expressions of modality, as well as any L1 interference errors.

\section{REFERENCES}

Charleston, B. M. (1941). Studies on the Syntax of the English Verb. Bern: Francke.

Collentine, J. (2010). The Acquisition and Teaching of the Spanish Subjunctive: An Update on Current Findings. Hispania 93: 39-51.

Drettas, G. (1987). Problèmes de linguistique balkanique. Bulletin de la Société de Linguistique de Paris (BSL) 82 (1): 257-281.

Goodwin, W. (2011). Syntax of the Moods and Tenses of the Greek Verb. Cambridge: Cambridge University Press.

Holton, D., Mackridge, P. Philippaki-Warburton, I. (1999). Greek: A Comprehensive Grammar of the Modern Language. London: Routledge.

Joseph, B., Philippaki-Warburton, I. (1987). Modern Greek. London - New York: Routledge.

Lakoff, R. (1968). Abstract syntax and Latin complementation. Cambridge - Mass: MIT Press.

Lightfoot, D. W. (1979). Principles of Diachronic Syntax. Cambridge: Cambridge University Press.

Psaltou-Joycey, A. (2003). Strategy use by Greek university students of English, in Selected Papers on Theoretical and Applied Linguistics. Proceedings of the $15^{\text {th }}$ Symposium on Theoretical and Applied Linguistics, ed. E. MelaAthanasopoulou (Thessaloniki: Aristotle University): 591-601.

Slabakova, R. (2005). What is so difficult about telicity marking in L2 Russian? Bilingualism: Language and Cognition 8: 63-77. 
Stojičić, V., Lampropoulou, M. (2020). Do you speak Greek? A case study of L2 Serbian learners of Greek. Teme 14/1: 251-266.

Stojičić, V., Lampropoulou, M., Janković, A. (2019). Interpretation of the subjunctive in Greek as L2: a case study of Serbian students. Анали Филолошког факултета 31/2: 391-410.

Tsangalidis, A. (1998). From Mood to Aspect: Grammaticalisation Theory and the Greek 'Aorist Subjunctive', in Proceedings of the $12^{\text {th }}$ International Conference on Theoretical and Applied Linguistics, ed. S. Lambropoulou

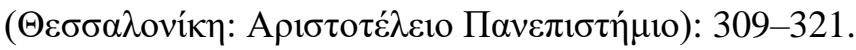

Van Der Auwera J., Zamorano Aguilar. A. (2016). The History of Modality and Mood, in The Oxford Handbook of Modality and Mood, eds. J. Nuyts and J. Van Der Auwera (Oxford: Oxford University Press): 1-21. DOI 10.1093/oxfordhb/9780199591435.013.4.

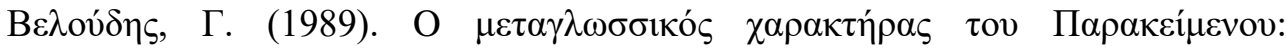

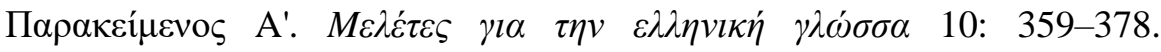
[Veloúdēs, G. (1989). O metaglōssikós kharaktếras tou Parakeímenou: Parakeímenos A'. Melétes gia tēn ellēnikè glốssa 10: 359-378].

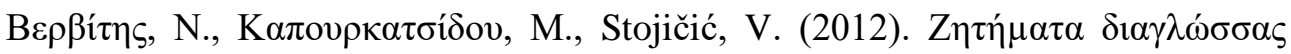

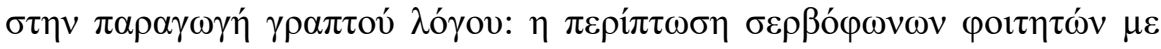
$\gamma \lambda \omega ́ \sigma \sigma \alpha \sigma \tau o ́ \chi 0 ~ \tau \eta \nu ~ E \lambda \lambda \eta v i \kappa \eta ́, ~ i n ~ S e l e c t e d ~ p a p e r s ~ o f ~ t h e ~ 10^{\text {th }}$ ICGL, eds. Z. Gavriilidou, A.Efthymiou, E. Thomadaki, P. Kambakis-Vougiouklis (Komotini: Democritus University of Thrace): 717-724. [Vervítēs, N., Kapourkatsídou, M., Stojičić, V. (2012). Zētếuata diaglốssas stēn paragōgé graptoú lógou: ē períptōsē servóphōnōn phoitētốn $\mu \mathrm{e}$ glốssa stókho tēn Ellēniké, in Selected papers of the 10th ICGL, eds. Z. Gavriilidou, A. Efthymiou, E. Thomadaki, P. Kambakis-Vougiouklis (Komotini: Democritus University of Thrace): 717-724].

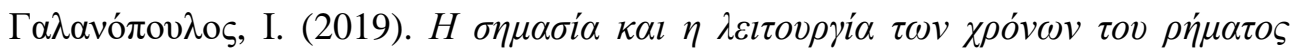

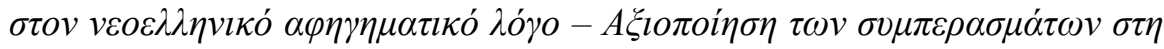

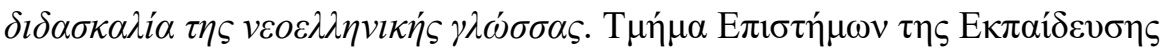

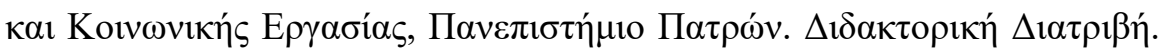
[Galanópoulos, I. (2019). E sēmasía kai è leitourgía tōn khrónōn tou rếmatos ston neoellēnikó aphēgēmatikó lógo - Axiopoiésē tōn sumperasmátōn stē didaskalía tēs neoellēnikés glốssas. Tmếma Epistếmōn tēs Ekpaídeusēs kai Koinōnikếs Ergasías, Panepistếmio Patrốn. Didaktorikế Diatrivế]. 


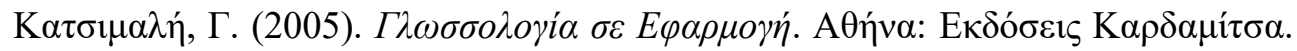
[Katsimalê, G. (2005). Glōssología se Epharmogé. Athếna: Ekdóseis Kardamítsa].

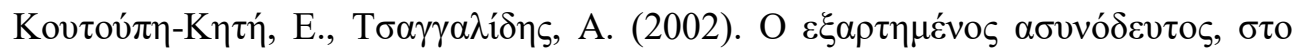

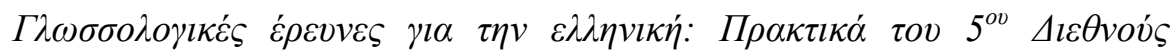

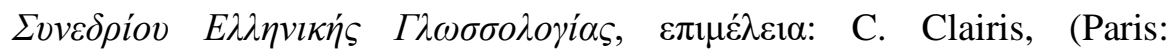
L’Harmattan): 309-312. [Koutoúpē-Kētế, E., Tsangalídēs, A. (2002). O exartēménos asunódeutos, sto Glōssologikés éreunes gia tēn ellēnikê: Praktiká tou 5ou Diethnoús Sunedríou Ellēnikếs Glōssologías, epiméleia: C. Clairis, (Paris: L'Harmattan): 309-312].

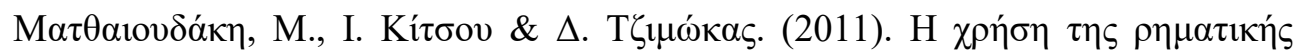

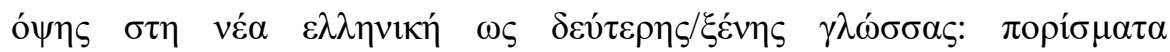

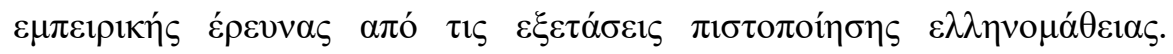

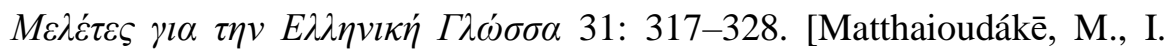
Kítsou \& D. Tzimốkas. (2011). Ē khrếsē tēs rēmatikếs ópsēs stē néa ellēnikế ōs deúterēs/xénēs glốssas: porísmata empeirikếs éreunas apó tis exetáseis pistopoíêsēs ellēnomátheias. Melétes gia tēn Ellēnikế Glốssa 31: 317-328].

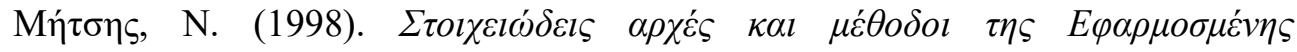

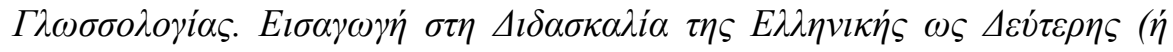

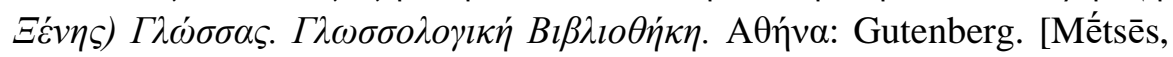
N. (1998). Stoikheiốdeis arkhés kai méthodoi tēs Epharmosménēs Glōssologías. Eisagōgè stè Didaskalía tēs Ellēnikè́s ōs Deúterēs (è Xénēs) Glốssas. Glōssologikế Vivliothékē. Athếna: Gutenberg].

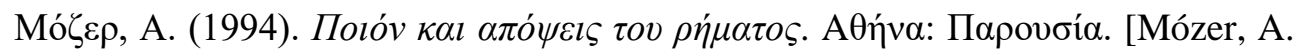
(1994). Poión kai apópseis tou rếmatos. Athếna: Parousía].

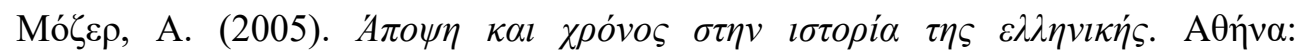
Парovбía. [Mózer, A. (2005). Ápopsē kai khrónos stēn istoría tēs ellēnikếs. Athếna: Parousía].

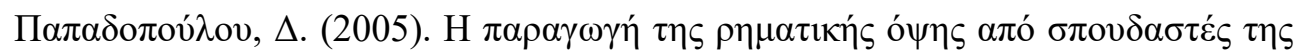

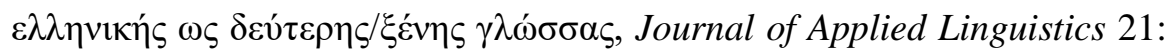
39-54. [Papadopoúlou, D. (2005). Ē paragōgế tēs rēmatikés ópsēs apó spoudastés tēs ellēnikếs ōs deúterēs/xénēs glốssas, Journal of Applied Linguistics 21: 39-54].

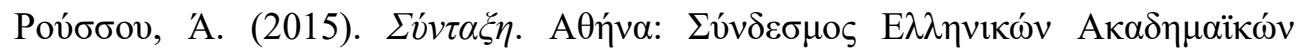

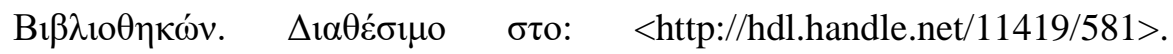
[Roússou, Á. (2015). Súntaxē. Athếna: Súndesmos Ellēnikốn 
Akadēmaïkốn Vivliothēkốn. Diathésimo sto: <http://hdl.handle.net/ $11419 / 581>]$.

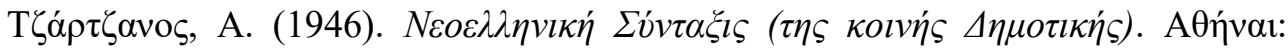

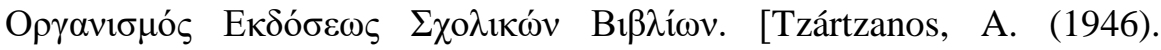
Neoellēniké Súntaxis (tēs koinếs Dēmotikếs). Athếnai: Organismós Ekdóseōs Skholikốn Vivlíōn].

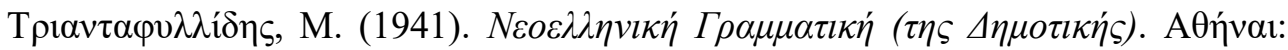

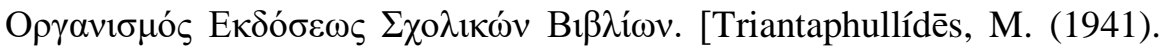
Neoellēnikế Grammatikế (tēs Dēmotikếs). Athếnai: Organismós Ekdóseōs Skholikốn Vivlíōn].

Пипер, П., Антонић, И., Ружић, В. и др. (2005). Синтакса савременога српског језика: Проста реченииа. Београд: Завод за уџбенике и наставна средства - Институт за српски језик. Нови Сад: Матица српска. [Piper, P., Antonić, I., Ružić, V. i dr. (2005). Sintaksa savremenoga srpskog jezika: Prosta rečenica. Beograd: Zavod za udžbenike i nastavna sredstva - Institut za srpski jezik. Novi Sad: Matica srpska].

Пипер, П., Клајн, И. (2017). Нормативна граматика српског језика. Нови Сад: Матица српска. [Piper, P., Klajn, I. (2017). Normativna gramatika srpskog jezika. Novi Sad: Matica srpska].

Рађеновић, А. (2017). Индикатив претерита у грчком и српском језику. Необјављена докторска дисертација. Београд: Филолошки факултет. [Rađenović, A. (2017). Indikativ preterita u grčkom i srpskom jeziku. Neobjavljena doktorska disertacija. Beograd: Filološki fakultet].

Станојчић, Ж. (2010). Граматика српског књижевног језика. Београд: Креативни центар. [Stanojčić, Ž. (2010). Gramatika srpskog književnog jezika. Beograd: Kreativni centar]. 
Војкан Б. Стојичић

Универзитет у Београду

Филолошки факултет

Марта П. Ламбропулу

Универзитет у Београду

Филолошки факултет

\section{ПЕРФЕКТИВНИ И ИМПЕРФЕКТИВНИ АСПЕКТ: СТУДИЈА СЛУЧАЈА СТУДЕНАТА НЕОХЕЛЕНИСТИКЕ}

\section{Сажетак}

Питање употребе перфективног или имперфективног облика глагола у модерном грчком језику заокупља пажњу многих лингводидактичара. Једна од најчешћих грешака у учењу модерног грчког језика као страног код србофоних говорника односи се на правилну употребу свршеног или несвршеног глаголског вида у граматичком систему овог језика. Модерни грчки језик показује аспектну морфологију у свим глаголским облицима, што значи да су сва времена аспектно одређена перфективношћу/имперфективношћу и не могу бити неутралне аспектуалности (Рађеновић, 2017). С тим у вези, спроведена је лонгитудинална студија која је подељена у два дела. Након представљеног теоријско-методолошког оквира који се односи на питања глаголског вида у модерном грчком и српском језику, приказани су резултати анализе писаних радова петнаест студената неохеленистике, током њиховог четворогодишњег школовања на Филолошком факултету Универзитета у Београду. За наше истраживање одабрали смо анализу писанога дискурса код студената неохеленистике, будући да се кроз писање састава на теме у којима се тражило давање савета и различитих упутстава претпоставила и већа употреба конјунктива аориста и футура тренутног у модерном грчком језику.

Резултати спроведеног истраживања указују на постојање негативног трансфера, односно интерференције код србофоних говорника, а изнети закључци износе додатне податке у односу на раније спроведена истраживања, која су за циљ имала анализу писаних радова ненативних говорника који уче модерни грчки као страни. Најзад, у раду се истиче важност анализе повратних информација које се могу добити из писаних радова студената неохеленистике, с циљем унапређивања универзитетске наставе модерног грчког језика као страног и да се овакав вид грешака смањи током учења језика.

Кључне речи: перфективни и имперфективни аспект, модерни грчки као страни, србофони студенти.

Received: 12 July 2021

Accepted: 8 August 2021 